\title{
Changes in nutrients and decay rate of Ginkgo biloba leaf litter exposed to elevated $\mathrm{O}_{3}$ concentration in urban area
}

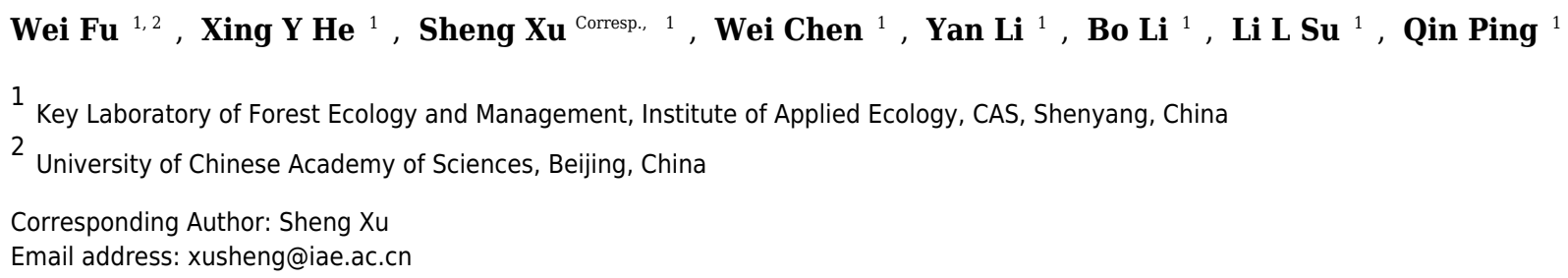

Ground-level ozone $\left(\mathrm{O}_{3}\right)$ pollution has been widely concerned in the world, particularly in the cities of Asia, including China. Elevated $\mathrm{O}_{3}$ concentrations have potentially influenced growth and nutrient cycling of trees in urban forest. The decomposition characteristics of urban tree litters under $\mathrm{O}_{3}$ exposure are still poorly known. Ginkgo biloba is commonly planted in the cities of northern China and is one of the main tree species in the urban forest of Shenyang, where concentrations of ground-level $\mathrm{O}_{3}$ are very high in summer. Here, we hypothesized that $\mathrm{O}_{3}$ exposure at high concentrations would alter the decomposition rate of urban tree litter. In open-top cambers (OTCs), 5-year-old G. biloba saplings were planted to investigate the impact of elevated $\mathrm{O}_{3}$ concentration (120 ppb) on changes in nutrient contents and decomposition rate of leaf litters. The results showed that elevated $\mathrm{O}_{3}$ concentration significantly increased $\mathrm{K}$ content $(6.31 \pm 0.29$ vs $17.93 \pm$ $0.40, P<0.01$ ) in leaves of $G$. biloba, significantly decreased the contents of total phenols ( $2.82 \pm 0.93$ vs $1.60 \pm 0.44, P<0.05)$ and soluble sugars ( $86.51 \pm 19.57$ vs $53.76 \pm 2.40$, $P<0.05)$, but did not significantly alter the contents of $C, N, P$, lignin and condensed tannins, compared with that in ambient air. Furthermore, percent mass remaining in litterbags after 150 days under ambient air and elevated $\mathrm{O}_{3}$ concentration was $56.0 \%$ and $52.8 \%$, respectively. No significant difference between treatments was observed in mass remaining at any sampling date during decomposition. The losses of the nutrients in leaf litters of $\mathrm{G}$. biloba showed significant seasonal differences regardless of $\mathrm{O}_{3}$ treatment. However, we found that elevated $\mathrm{O}_{3}$ concentration slowed down the leaf litter decomposition only at the early decomposition stage, but slightly accelerated the litter decomposition at the late stage (after 120 days). This study provides our understanding of the ecological processes regulating biogeochemical cycles from deciduous tree species in high- $\mathrm{O}_{3}$ urban area. 
1 Changes in nutrients and decay rate of Ginkgo biloba leaf litter exposed to elevated $\mathrm{O}_{3}$

\section{ABSTRACT}

7 Ground-level ozone $\left(\mathrm{O}_{3}\right)$ pollution has been widely concerned in the world, particularly in the 8 cities of Asia, including China. Elevated $\mathrm{O}_{3}$ concentrations have potentially influenced growth
Wei $\mathrm{Fu}^{1,2}$, Xingyuan $\mathrm{He}^{1}$, Sheng $\mathrm{Xu}^{1, *}$, Wei Chen ${ }^{1}$, Yan $\mathrm{Li}^{1}$, Bo Li ${ }^{1}$, Lili $\mathrm{Su}^{1}$, Qin Ping ${ }^{1}$

${ }^{1}$ Key Laboratory of Forest Ecology and Management, Institute of Applied Ecology, CAS, Shenyang, China

${ }^{2}$ University of Chinese Academy of Sciences, Beijing, China and nutrient cycling of trees in urban forest. The decomposition characteristics of urban tree litters under $\mathrm{O}_{3}$ exposure are still poorly known. Ginkgo biloba is commonly planted in the cities of northern China and is one of the main tree species in the urban forest of Shenyang, where concentrations of ground-level $\mathrm{O}_{3}$ are very high in summer. Here, we hypothesized that $\mathrm{O}_{3}$ exposure at high concentrations would alter the decomposition rate of urban tree litter. In opentop cambers (OTCs), 5-year-old G. biloba saplings were planted to investigate the impact of elevated $\mathrm{O}_{3}$ concentration $(120 \mathrm{ppb})$ on changes in nutrient contents and decomposition rate of leaf litters. The results showed that elevated $\mathrm{O}_{3}$ concentration significantly increased $\mathrm{K}$ content $(6.31 \pm 0.29$ vs $17.93 \pm 0.40, P<0.01)$ in leaves of $G$. biloba, significantly decreased the contents of total phenols $(2.82 \pm 0.93$ vs $1.60 \pm 0.44, P<0.05)$ and soluble sugars $(86.51 \pm 19.57$ vs 53.76 $\pm 2.40, P<0.05$ ), but did not significantly alter the contents of $\mathrm{C}, \mathrm{N}, \mathrm{P}$, lignin and condensed tannins, compared with that in ambient air. Furthermore, percent mass remaining in litterbags after 150 days under ambient air and elevated $\mathrm{O}_{3}$ concentration was $56.0 \%$ and 52.8\%, respectively. No significant difference between treatments was observed in mass remaining at any sampling date during decomposition. The losses of the nutrients in leaf litters of G. biloba showed significant seasonal differences regardless of $\mathrm{O}_{3}$ treatment. However, we found that elevated $\mathrm{O}_{3}$ concentration slowed down the leaf litter decomposition only at the early decomposition stage, but slightly accelerated the litter decomposition at the late stage (after 120 days). This study provides our understanding of the ecological processes regulating biogeochemical cycles from deciduous tree species in high- $\mathrm{O}_{3}$ urban area.

* Corresponding author: Sheng Xu, shengxu703@126.com 


\section{INTRODUCTION}

31 In recent decades, due to the large increases in the emission of $\mathrm{O}_{3}$ precursors including $\mathrm{NO}_{x}$ and

32 VOCs around the world, the ground-level $\mathrm{O}_{3}$ concentrations are constantly increasing,

33 particularly in Asia (Sitch et al., 2007; IPCC, 2013). It is estimated that the $\mathrm{O}_{3}$ concentration in

34 the troposphere will increase by $40 \%$ to $60 \%$ by 2100 (Akimotoa et al., 2015). Among air

35 pollutants, $\mathrm{O}_{3}$ has the most widespread negative impact on terrestrial vegetation. In particular, it 36 may potentially influences on biogeochemical cycles of forest ecosystems (Nikolova et al., 2010;

37 Calatayud et al., 2011; Sicard et al., 2016).

38 Effects of $\mathrm{O}_{3}$ on forest ecosystems productivity and feedbacks have been widely investigated 39 worldwide (Chappelka and Samuelson, 1998; Paoletti, 2006; de Bauer and Hernández-Tejeda, 40 2007) and recently were reviewed (Wang et al., 2016). Differently, $\mathrm{O}_{3}$ effects on litter 41 decomposition are much less known (Nikula et al., 2010). Indirect evidence comes from litter 42 photodegradation studies in semi-arid and arid ecosystems (Austin and Vivanco, 2006). Among 43 the few studies carried out in natural forest ecosystems, Parsons et al. (2008) showed that, over a 44 23-months observation period on leaf litterbags of aspen and birch reciprocally transplanted to 45 separate the effect of substrate quality from environment effects, increasing $\mathrm{O}_{3}$ concentration by 46 fumigation slowed down both aspen and birch litter decay rate, exacerbating the effects of 47 elevated $\mathrm{CO}_{2}$ concentration, but accelerated birch litter decay under ambient $\mathrm{CO}_{2}$. A negative 48 effect of $\mathrm{O}_{3}$ fumigation on litter decay rate was also observed for holm oak leaf litter in

49 Mediterranean forest (Baldantoni et al., 2011). Such observations were explained by $\mathrm{CO}_{2}$ - and $50 \mathrm{O}_{3}$-mediated changes in litter chemistry, particularly carbohydrates, nitrogen, and tannins. $\mathrm{O}_{3}$

51 effects on litter decomposition in urban forests have not yet been explored. Filling such gap is 52 particularly important, as in urban ecosystems, where tropospheric $\mathrm{O}_{3}$ concentration can be very 53 high due to photochemical air pollution; urban trees play a fundamental role in mitigating air 
54 pollution (Manes et al., 2012). Their leaf litter, if decaying faster when exposed to high $\mathrm{O}_{3}$

55 concentration, would improve soil chemical properties and promote nutrient cycles, therefore

56 affecting the sustainable development of urban areas (Nikula et al., 2010; Xu et al., 2012).

57 Ginkgo biloba is commonly planted in the cities of northern China and it is one of the main

58 tree species in the urban forest of Shenyang, Liaoning Province, China. According to our recent

59 observations, the highest $\mathrm{O}_{3}$ concentration at ground level is frequently over 40 ppb or even up to

60 more than $80 \mathrm{ppb}$ during the summer in the urban area of Shenyang city (Xu et al., 2015). For

61 many years, we assessed the effects of elevated $\mathrm{O}_{3}$ concentration on the eco-physiology of urban

62 trees including G. biloba (He et al., 2009; Lu et al., 2009; Li et al., 2011; Xu et al., 2015). Here

63 we aim to complement such previous studies with a manipulative experiment testing $\mathrm{O}_{3}$ effects on

64 G. biloba leaf litter decomposition and chemical features. Based on the results of many previous

65 studies, we hypothesized that $\mathrm{O}_{3}$ exposure at high concentrations commonly experienced by

66 urban trees, could alter chemical composition and decrease the decomposition rate of this tree

67 leaf litter. In this study, we predicted that elevated $\mathrm{O}_{3}$ concentration would change the chemical

68 compositions of leaves and decomposition rate of leaf litter. Therefore, the main objectives of this

69 study are 1) to assess the changes of leaf litter quality of $G$. biloba fumigated by elevated $\mathrm{O}_{3}$

70 concentration, including the changes in the contents of some nutrients and secondary metabolites,

71 and 2) to evaluate the decomposition rates of leaf litter from this gymnosperm tree species

72 exposed to high $\mathrm{O}_{3}$ concentration.

\section{MATERIALS \& METHODS}

\section{Study site and experimental treatments}

75 The study was conducted in Shenyang Arboretum of Chinese Academy of Sciences $\left(41^{\circ} 46^{\prime} \mathrm{N}\right.$,

$\left.76123^{\circ} 26^{\prime} \mathrm{E}\right)$ located in an urban area (He et al., 2009). The arboretum with a mean elevation of 41 
$77 \mathrm{~m}$ and an area of 5 ha was founded in 1955, mainly planted with native tree species. There are

78 more than 300 tree species and the forest coverage rate was 53.7\% (He et al., 2016). Nowadays,

79 it has been a near-natural urban forest (He et al., 2003). Affected by warm temperate-zone semi-

80 humid monsoon climate, this area has an annual average temperature of 6.2 to $9.7^{\circ} \mathrm{C}$. The average

81 temperatures in January and July are -12.6 and $27.5^{\circ} \mathrm{C}$, respectively. The maximum temperature

82 is $38.3^{\circ} \mathrm{C}$ and the minimum temperature is $-30.5^{\circ} \mathrm{C}(X u$ et al., 2014). The average annual

83 precipitation is $755.4 \mathrm{~mm}$. The frost-free period lasts for $150 \mathrm{~d}$ yearly ( $X u$ et al., 2005). The flora

84 of the arboretum located area belongs to the intersection of Changbai Mountain, Northern China,

85 and the Mongolian Floras (Xu et al., 2006).

86 This experiment was carried out in open-top cambers (OTCs). Chambers are $4 \mathrm{~m}$ in diameter

87 and $3 \mathrm{~m}$ in height, with a $45^{\circ}$ sloping frustum and 4-m distance between neighbouring OTCs ( $\mathrm{Li}$

88 et al., 2011; Xu et al., 2015). This experiment included control in ambient air (AA, about 40 ppb)

89 and elevated $\mathrm{O}_{3}$ concentration $(\mathrm{EO}, 120 \mathrm{ppb})$. AA and $\mathrm{EO}$ had three independent OTC replicates

90 with three OTCs, respectively. Six OTCs were used in total. In 20 May, 2012, nine healthy and

91 uniform five-year-old saplings of G. biloba (1.5 $\mathrm{m}$ in average height) from a local nursery were

92 selected and planted in each OTC. During the growing season, the saplings were irrigated twice a

93 week and fertilized once at the beginning of the experiment. After $60 \mathrm{~d}$ (20 July), the saplings

94 were fumigated with $\mathrm{O}_{3}$ for $8 \mathrm{~h}$ a day from 9:00-17:00, except in bad weather such as

95 thunderstorm conditions. By the end of fumigation on 5 November, 2012, all the yellow

96 (senescent) leaves of G. biloba from each chamber were harvested and regarded as leaf litter.

97 These senescent leaves under AA and EO were randomly divided into two parts: one part was

98 dried at $65^{\circ} \mathrm{C}$ to constant weight for determining the initial chemical compositions and the other

99 was sufficiently dried, and stored in a big glass container and then kept at a cool place under

100 room temperature for the litter decomposition experiments in OTCs next year (2013). 
101 The leaf litters were decomposed according to the litterbag method (Zhang et al., 2015) by 102 placing them in nylon bags $(20 \mathrm{~cm} \times 25 \mathrm{~cm})$ with $1 \mathrm{~mm}^{2}$ mesh. Before the experiment, each bag 103 was filled with $8 \mathrm{~g}$ samples and numbered. On 19 May, 2013, 15 bags were placed into each OTC 104 to touch the topsoil and separate them at 10-cm intervals each other. A total of 45 bags of AA and

105 EO were prepared, respectively. Before putting the litter bags into OTCs, the topsoil $(0-10 \mathrm{~cm})$ of 106 each treatment was gathered after removing weeds and other sundries from the ground. Soil 107 samples were mixed uniformly after the stones, roots and other debris were removed.

108 Homogenized fresh soil was passed through a sieve (pore size was $5 \mathrm{~mm}$ ) and dried under natural 109 conditions. The basic physical and chemical properties of topsoil $(0-10 \mathrm{~cm})$ are shown in Table 1.

$110 \mathrm{O}_{3}$ fumigation was carried out for $8 \mathrm{~h}$ each day (9:00-17:00). The samples were collected once a

111 month (Sampling date is 19 every month from June to October) to be decomposed for 150 days in

112 total. $\mathrm{O}_{3}$ concentrations were monitored every day throughout the growing period (19 May-20

113 October 2013), at $0.80 \mathrm{~m}$ above the ground, in the OTCs of both AA and EO (Figure 1). The

114 microclimatic conditions in the OTCs during litter decomposition are summarised in Table 2.

115 After washing and drying, the cleaned litters were placed into Kraft envelope bags and oven116 dried at a constant temperature of $65^{\circ} \mathrm{C}$. Afterwards, leaf litters were weighed and dry mass were 117 pulverised by a high-speed grinding machine (FW-100, Tianjing, China) and filtered through a 118 sieve ( 80 meshes, mesh size is $5 \mathrm{~mm}$ ). The powdered samples were preserved in self-sealing bags 119 for the laboratory measurements.

\section{Chemical analyses and experimental statistics}

121 Carbon (C) and nitrogen (N) contents were determined by an elemental analyser (Vario MACRO 122 Cube, Elementar, Germany). Phosphorus (P) and potassium (K) contents were measured by 123 atomic absorption spectrometry (AA800, PerkinElmer, USA) according to the Mo-Sb 124 colorimetric method and flame photometric method, respectively. Lignin content was determined 
125 using the ultraviolet spectrophotometric method (Liyama and Wallis, 1988) and total phenol

126 content was measured according to the method of Julkunen-Tiitto (1985) with a minor

127 modification. The condensed tannins and soluble sugar contents were determined by

128 spectrophotometer (UV-1800, Shimadzu, Japan) according to the butyl alcohol-hydrochloric acid

129 method (Porter et al., 1986) and anthrone colorimetric method (Dubois et al., 1956), respectively.

130 Mass remaining of leaf litter over time, expressed as percentage of the initial value, was

131 calculated according to the assumed simple exponential model formulated by Olson (1963).

$132 Y=A_{\mathrm{t}} / A_{0}=\mathrm{e}^{-k t}$. Where, $Y, A_{0}$ and $A_{\mathrm{t}}$ indicate the remaining rate of litter mass monthly, the

133 initial litter mass (g), and the remaining mass (g) of leaf litter at time $t$ (months), respectively. In

134 addition, e, and $k$ are the base of natural logarithms, and the decomposition coefficient of the

135 litters, respectively. As for $t$, it is the decomposition time (months) including the half-life of

136 decomposition $\left(t_{0.5}=\ln (2) / k\right)$.

137 The remaining rate of nutrient composition was calculated (Pancotto et al., 2003):

$138 E=\left[\left(M_{\mathrm{t}} \times C_{\mathrm{t}}\right) /\left(M_{0} \times C_{0}\right)\right] \times 100 \%$

139 Where, $E, M_{\mathrm{t}}, M_{0}, C_{0}$, and $C_{\mathrm{t}}$ represent the remaining (\% initial) of nutrient elements, dry

140 mass ( $\mathrm{g}$ ) of leaf litter at the designated time of decomposition, initial dry mass (g), initial nutrient

141 content $\left(\mathrm{mg} \cdot \mathrm{g}^{-1}\right)$, and nutrient content $\left(\mathrm{mg} \cdot \mathrm{g}^{-1}\right)$ of leaf litter at the designated time of

142 decomposition, respectively.

143 Data analyses were performed using SPSS 18.0 (SPSS Inc., Chicago, IL, USA). General

144 linear model (GLM) was used to evaluate and analyse the dynamics of leaf litter mass remaining,

145 changes in $\mathrm{C}, \mathrm{N}, \mathrm{P}$, lignin, total phenols, condensed tannin and soluble sugar contents with

146 considering the treatments (two levels), decomposition time (continuous variable), as well as

147 their interaction, as independent factors. All data were presented as mean \pm standard deviation.

148 Significant differences between control (ambient air, AA) and elevated $\mathrm{O}_{3}$ concentration (EO) 
149 were tested by T-test.

150 RESULTS

151 Changes in chemical compositions in leaf litters of $G$.. biloba after exposure to EO

152 In comparison with AA, EO decreased C content (by 26.1\%), but increased slightly $\mathrm{N}$ content (by

$15311.3 \%$ ) in leaves of G. biloba by the end of growing season (Figure 2). EO decreased C/N ratio

154 (by 10.3\%). P content decreased under $\mathrm{O}_{3}$ fumigation. However, changes in $\mathrm{C}, \mathrm{N}, \mathrm{P}$ and $\mathrm{C} / \mathrm{N}$ were

155 not significant. EO significantly increased the K content by $184.2 \%(6.31 \pm 0.29$ vs $17.93 \pm 0.40$, $156 P<0.01)$ compared with AA (Figure 2).

157 In addition, EO decreased the contents of lignin (by 8.6\%) and condensed tannins (by 158 17.5\%). By contrast, the difference between EO and AA was not significant (Figure 2). EO 159 significantly decreased the contents of total phenolics $(2.82 \pm 0.93$ vs $1.60 \pm 0.44, P<0.05)$ and 160 soluble sugar $(86.51 \pm 19.57$ vs $53.76 \pm 2.40, P<0.05)$ by $43.3 \%$ and $37.9 \%$ compared with AA, 161 respectively.

\section{Dynamics of leaf litter decomposition of $G$. biloba exposed to EO}

163 Based on the Olson's model, the decay constant and the half-life decomposition time of the leaf

164 litters of G. biloba under EO were lower than those AA, showing no significant difference (Table

165 3). Compared with AA, the mass (dry weight) remaining of leaf litters under EO maintained a 166 higher level at early stage of decomposition (before 60-day sampling point), but decreased with 167 decomposition time after 90 days, and it was 5.8\% lower than that of AA at 150-day sampling 168 point (Figure 3A). No significant difference between AA and EO was observed in mass 169 remaining of $G$. biloba leaf litter over time. $\mathrm{O}_{3}$ fumigation reduced the remaining of $\mathrm{C}$ in leaf 170 litter and a significant difference between AA and EO was found after 120 days (EO decreased by 
$1718.3 \%$ compared with that of AA) (Figure 3B). By contrast, N remaining showed a lower level

172 after 90 days under EO than that of AA. However, no significant difference was found in $\mathrm{N}$

173 remaining between treatments during decomposition (Figure 3C). P remaining in leaf litter

174 showed higher level under EO than AA, and decreased dramatically after 60 days and reached a

175 lowest value at 90-day sampling point (11.2\%) (Figure 3D).

176 The remaining of lignin in leaf litters of G.. biloba showed a significant decreasing trend

177 regardless of $\mathrm{O}_{3}$ treatment during decomposition (Figure 3E, Table 4, $P<0.001$ ). Compared

178 with the AA, the remaining of lignin under EO was quite lower after 120 days, indicating an

179 increasing of lignin decomposition rate. However, no significant effect was observed in the

180 remaining of lignin under EO (Table 4, $P=0.249$ ). After 60 days, the remaining of total phenol

181 content showed a significant decrease under EO at each sampling point (Figure 3F), compared

182 with AA $(P<0.05)$. A significant interactive effect of $\mathrm{O}_{3}$ concentration and decomposition time

183 was found for the total phenol remaining (Table 4, $P=0.002$ ). EO showed no significant effect

184 on the decomposition of condensed tannins during the experiment (Figure $3 \mathrm{G}$, Table $4, P=$

185 0.326). During decomposition, the remaining of soluble sugar showed a significant higher lever

186 at each sampling point except for the 90-day sampling point under EO than AA $\left(\begin{array}{lll}P<0.05\end{array}\right)$

187 (Figure 3H).

\section{DISCUSSION}

189 Effect of elevated $\mathrm{O}_{3}$ concentration on chemical composition of $G$.. biloba leaf litter

190 The results of our study showed that elevated $\mathrm{O}_{3}$ concentration $(120 \mathrm{ppb})$ increased $\mathrm{N}$ and $\mathrm{K}$

191 contents in leaf litter of G.. biloba, but significantly decreased the total phenol content, as well as

192 the $\mathrm{C} / \mathrm{N}$ and lignin/ $\mathrm{N}$ ratios. However, the $\mathrm{P}$ and lignin contents, as well as the $\mathrm{C} / \mathrm{P}$ ratio did not 193 change significantly. Actually, elevated $\mathrm{O}_{3}$ concentration usually changes the chemical 
194 composition of plants (Calatayud et al., 2011; Shang et al., 2018). Booker et al. (2005) found that

195 the changes in $\mathrm{N}$ and lignin contents of soybean leaf litter increase significantly, while the soluble

196 sugar content significantly decreased under elevated $\mathrm{O}_{3}$ concentration $(74 \mathrm{ppb})$, in agreement

197 with our results in this study. Parsons et al. (2004) tested the impact of high $\mathrm{O}_{3}$ concentration (55

$198 \mathrm{ppb}$ ) on leaf litter of Betula papyrifera for 12 months. The results demonstrated that the contents

199 of $\mathrm{N}$, lignin, and condensed tannins, as well as the $\mathrm{C} / \mathrm{N}$ ratio of leaf litter showed no significant

200 change under elevated $\mathrm{O}_{3}$ concentration, compared to tests in ambient air conditions.

201 In our study, the increasing of $\mathrm{N}$ content in $G$. biloba leaves after high $\mathrm{O}_{3}$ exposure may be a

202 helpful response to prevent the damage caused by $\mathrm{O}_{3}$ to some extent (Cao et al., 2016). High $\mathrm{N}$

203 concentration in leaves could make plants adapt to $\mathrm{O}_{3}$ stress through leaf turnover (Tjoelker and

204 Luxmoore, 1991; Shang et al., 2018). In addition, the $\mathrm{C} / \mathrm{N}$ ratio was an important indicator for the

205 degree of coordination of $\mathrm{C}$ and $\mathrm{N}$ metabolism. Reduction of $\mathrm{C} / \mathrm{N}$ in plants under elevated $\mathrm{O}_{3}$

206 concentration showed that the growth of plants was inhibited (Zheng et al., 2011), in agreement

207 with our result that $\mathrm{C} / \mathrm{N}$ ratio decreased under $\mathrm{O}_{3}$ fumigation. Zhang et al. (2011) demonstrated

208 that elevated $\mathrm{O}_{3}$ concentration promoted $\mathrm{K}$ absorption during growth of plants. Furthermore, $\mathrm{K}$

209 increased $\mathrm{N}$ absorption in order to transfer it into proteins under adverse environment. The

210 increase of $\mathrm{K}$ contents in our study was possibly one of the reasons why $\mathrm{N}$ content increased

211 under elevated $\mathrm{O}_{3}$ concentration.

212 Plant secondary substances play a pivotal role in scavenging the high level of oxygen

213 species caused by ozone at the end of $\mathrm{O}_{3}$ fumigation (He et al., 2009). Generally, the secondary

214 metabolic enzymes such as phenylalanine ammonia lyase (PAL), peroxidase (POD), and

215 polyphenol oxidase (PPO) are involved in the synthesis of secondary substances (Tiwari et al.,

216 2016). Luo and Zhang (2010) found that elevated $\mathrm{O}_{3}$ concentration significantly decreased the

217 lignin contents of plants by inhibiting the activities of PAL, POD and PPO. In our study, the 
218 decrease of lignin content in G. biloba leaves could be due to the inhibition of activities of

219 relevant enzyme for synthesising lignin by elevated $\mathrm{O}_{3}$ concentration.

220 Phenolic compounds are the main products of secondary metabolism and are important

221 defence substances in plants. Some research demonstrated that elevated $\mathrm{O}_{3}$ concentrations

222 increased the contents of phenolic compounds in leaves (Yamaji et al., 2003; Peltonen et al.,

223 2005). In our previous studies, elevated $\mathrm{O}_{3}$ concentration ( $\left.80 \mathrm{ppb}\right)$ significantly increased the

224 total phenolics and condensed tannin contents in leaves of Quercus mongolica, leading to the

225 increasing of the antioxidant capacity of plants to $\mathrm{O}_{3}$ stress (Zhang et al., 2009). In this study,

226 elevated $\mathrm{O}_{3}$ concentration decreased the contents of condensed tannins and total phenols of $G$..

227 biloba leaves. It could be due to the produce of a large number of free radicals under $\mathrm{O}_{3}$ stress,

228 leading to many antioxidant substances including phenolic compounds were consumed by the

229 end of the growing season (He et al., 2009). Therefore, the decreases of condensed tannins and

230 total phenolic content in $G$. biloba leaves may increase the sensitivity of the leaf injuries to $\mathrm{O}_{3}$

231 (Yamaji et al., 2003). Actually, no effect of elevated $\mathrm{O}_{3}$ concentrations on the contents of

232 condensed tannins and phenolic compounds was reported by some studies (Lavola et al., 1994;

233 Lindroth et al., 2001), not in agreement with our current results due to the differences in tree

234 species and $\mathrm{O}_{3}$ concentrations to some extent.

235 Soluble sugar plays an important role in plant metabolism under adverse environments (Liu

236 et al., 2004). Wang et al. (2011) reported that $\mathrm{O}_{3}$ fumigation (60 ppb, 50\% above ambient air)

237 significantly decreased the soluble sugar content of rice in each growth stage. However, Lu et al.

238 (2012) found that the content of soluble sugar in the leaves of Mangifera indica increased under

$239 \mathrm{O}_{3}$ concentration $(50 \mathrm{ppb})$, but decreased significantly under a high- $\mathrm{O}_{3}$ concentration $(200 \mathrm{ppb})$,

240 in agreement with our result that the soluble sugar contents in leaves of G.. biloba decreased

241 significantly under elevated $\mathrm{O}_{3}$ concentration $(120 \mathrm{ppb})$. The reason for this was probably due to 
242 the accumulation of glycolytic enzymes in leaves, which accelerated the degradation of sugar

243 components (Tiwari et al., 2016).

244 Effect of elevated $\mathrm{O}_{3}$ concentration on the decomposition rate of $\mathbf{G}$. biloba leaf litter

245 Elevated $\mathrm{O}_{3}$ concentration not only changes the chemical composition of leaf litter, but also

246 indirectly affects the litter decomposition (Baldantoni et al., 2011). In this study, the remaining

247 mass of dry weight of G. biloba leaf litter showed significant positive correlation with the C, N,

$248 \mathrm{P}$, and lignin contents as well as the ratios of $\mathrm{C} / \mathrm{N}$ and lignin/ $\mathrm{N}$, regardless of $\mathrm{O}_{3}$ treatment (Table

249 5). This indicated that the higher the contents of $C, N, P$, and lignin, the higher the mass

250 remaining, and the lower the decomposition rate (Bonanomi et al., 2013). In this study, the mass

251 remaining are larger under elevated $\mathrm{O}_{3}$ concentration than under ambient air at early

252 decomposition stage, which implied that the decomposition of leaf litter slowed down under $\mathrm{O}_{3}$

253 fumigation. This is consistent with most of the previous studies showing that elevated $\mathrm{O}_{3}$ has

254 adverse effects on litter decomposition (Parsons et al., 2008; Liu et al., 2009; Baldantoni et al.,

255 2011). At the late stage of decomposition (after 90 days), the mass remaining of leaf litter showed

256 higher level under ambient air than elevated $\mathrm{O}_{3}$ treatment, which indicated that $\mathrm{O}_{3}$ slightly

257 increased the decay rate of leaf litter by impacting litter quality in this study. Indeed, Litter

258 quality is the most important factor affecting mass loss and decay rates of nutrients (Bonanomi et

259 al., 2010).

260 In fact, $\mathrm{O}_{3}$ exposure has not always led to reduction in litter decomposition rate of tree

261 species (Scherzer et al., 1998; Kainulainen et al., 2003). In our recent study, we observed that N

262 mineralization and lignin degradation in leaf litters of $Q$. mongolica under elevated $\mathrm{O}_{3}$

263 concentration (120 ppb) were inhibited during early stage of decomposition, but promoted at later

264 stage of decomposition ( $\mathrm{Su}$ et al., 2016). Indeed, as the major component in leaf litter, lignin has

265 a complex structure and is difficult to decompose (Peng and Liu, 2002). During the 
266 decomposition in this experiment, the remaining rates of lignin, condensed tannin and total

267 phenols were lower under elevated $\mathrm{O}_{3}$ concentration than under ambient air at late decomposition

268 stage, which implied that elevated $\mathrm{O}_{3}$ concentration promoted the decomposition of leaf litter.

269 The slight promotion of the decomposition rate of leaf litter mainly resulted from the decrease of

270 leaf litter quality induced by $\mathrm{O}_{3}$ fumigation. Besides, exposure of $\mathrm{O}_{3}$ at the late decomposition

271 stage of the experiment might accelerate the oxidation and decomposition of secondary metabolic

272 substances (Su et al., 2016).

273 Unlike the remaining of lignin, condensed tannin and total phenols, the remaining of soluble

274 sugar showed higher values under elevated $\mathrm{O}_{3}$ concentration than ambient air at any sampling

275 point during litter decomposition. The lower decay rate observed for ozone-exposed leaves could

276 be due to changes in both structural and functional molecules that we did not study here or

277 decreases in the activities of enzymes relating to carbohydrate metabolism under $\mathrm{O}_{3}$

278 exposure (Peace et al., 1995). In addition, the higher value of carbohydrate remaining was

279 maintained under $\mathrm{O}_{3}$ fumigation during decomposition and becoming much smaller difference

280 between AA and EO by the end of the experiment, which might result from inhibiting effect of $\mathrm{O}_{3}$

281 on decay rates of leaf litter with high initial values at early decomposition stage. The similar

282 results were observed in some previous studies (Fioretto et al., 2005; Liu et al., 2009).

\section{CONCLUSIONS}

284 In this study, we found that elevated $\mathrm{O}_{3}$ showed no significant impact on chemical compositions

285 and decay rates of $G$. biloba, although it decreased the contents of $\mathrm{C}, \mathrm{P}, \mathrm{C} / \mathrm{N}$ ratio, lignin, total

286 phenols, condensed tannins, and soluble sugars in G. biloba leaves by the end of gas fumigation.

287 In fact, $\mathrm{O}_{3}$ fumigation slightly inhibited the decomposition of G. biloba leaf litter at the early

288 stages of decomposition, but increased decomposition rate at late stages of this experiment.

289 During the whole decomposition, the losses of the nutrients in leaf litters of G. biloba showed 
290 significant seasonal differences regardless of $\mathrm{O}_{3}$ treatment. Rising atmospheric $\mathrm{O}_{3}$ concentration

291 will likely elicit species-specific effects on litter production and decomposition in urban forests,

292 retarding decay rates in some species such as birch (Parsons et al., 2008), while potentially

293 exerting little effect on others. Furthermore, elevated $\mathrm{O}_{3}$ will not exert its influence on litter decay

294 rates in isolation from other factors including soil microorganism, although the results from our

295 study showed that $\mathrm{O}_{3}$ in current concentration in this study had little (not significant) effect on

296 decomposition of G. biloba leaf litter. Our results indicated that the ground-level $\mathrm{O}_{3}$

297 concentrations in some cities of China could significantly alter the chemical compositions and

298 decomposition rates of at least one deciduous gymnosperm tree species once suffering from long-

299 time exposure of higher $\mathrm{O}_{3}$ concentration. These changes are likely to have important

300 implications for our understanding of the processes regulating the storage and emission of $\mathrm{C}$ from

301 urban forest ecosystems under climate change. Therefore, further research for the long-term $\mathrm{O}_{3}$

302 exposure of urban trees (only one growing season in this study) is necessary to determine the

303 nutrient cycling and sustainability of main tree species with different ages including G. biloba in

304 urban forest, where $\mathrm{O}_{3}$ is one of the most widespread of all the gaseous pollutants in urban area.

\section{REFERENCES}

306 Akimotoa H, Morib Y, Sasaki K, Itano Y. 2015. Analysis of monitoring data of ground-level ozone in Japan for 307 long term trend during 1990-2010: Causes of temporal and spatial variation. Atmospheric Environment $308 \quad$ 102: $302-310$

309 Austin AT, Vivanco L. 2006. Plant litter decomposition in a semi-arid ecosystem controlled by 310 photodegradation. Nature 442: 555-558

311 Baldantoni D, Fagnano M, Alfani A. 2011. Tropospheric ozone effects on chemical composition and 312 decomposition rate of Quercus ilex L. leaves. Science of the Total Environment 409: 979-984

313 Bonanomi G, Incerti G, Antignani V, Capodilupo M, Mazzoleni S. 2010. Decomposition and nutrient dynamics 314 in mixed litter of Mediterranean species. Plant Soil 331: 481-496

315 Bonanomi G, Incerti G, Giannino F, Mingo A, Lanzotti V, Mazzoleni S. 2013. Litter quality assessed by solid 
316

317

318

319

320

321

322

323

324

325

326

327

328

329

330

331

332

333

334

335

336

337

338

339

340

341

342

343

344

345

346

347

state ${ }^{13} \mathrm{C}$ NMR spectroscopy predicts decay rate better than $\mathrm{C} / \mathrm{N}$ and Lignin/N ratios. Soil Biology \& Biochemistry 56: 40-48

Booker FL, Prior SA, Torbert HA, Hu S. 2005. Decomposition of soybean grown under elevated concentrations of $\mathrm{CO}_{2}$ and $\mathrm{O}_{3}$. Global Change Biology 11: 685-698

Calatayud V, Cerveró J, Calvo E, Garcia FJ, Armiriana JR. 2011. Responses of evergreen and deciduous Quercus species to enhanced ozone levels. Environment Pollution 159: 55-63

Cao JX, Shang H, Chen Z, Tian Y, Yu H. 2016. Effects of elevated ozone on stoichiometry and nutrient pools of Phoebe Bournei (Hemsl.) Yang and Phoebe Zhennan S. Lee et FN Wei seedlings in subtropical China. Forests 7: 78-88

Chappelka AH, Samuelson LJ. 1998. Ambient ozone effects on forest trees of the eastern United States: a review. New Phytologist 139: 91-108

de Bauer MDL, Hernández-Tejeda T. 2007. A review of ozone-induced effects on the forests of central Mexico. Environmental Pollution 147: 446-453

Dubois M, Gilles KA, Hamilton JK, Rebers PA, Smith F. 1956. Colorimetric method for determination of sugars and related substances. Analytical Chemistry 28: 350-356

Fioretto A, Di Nardo C, Papa S, Fuggi A. 2005. Lignin and cellulose degradation and nitrogen dynamics during decomposition of three leaf litter species in a Mediterranean ecosystem. Soil Biology and Biochemistry 37: 1083-1091

He X, Chen W, Xu W, Liu C, Zhu W, Jin Y, Zhang Y. 2003. Community ecology in a typical near natural urban forest. Chinese Journal of Ecology 22: 162-168

He X, Xu S, Xu W, Chen W, Huang Y, Wen H. 2016. Effects of Climate Warming on Phenological Characteristics of Urban Forest in Shenyang City, China. Chinese Geographical Science 26: 1-9

He XY, Huang W, Chen W, Dong T, Liu C, Chen Z, Xu S, Ruan Y. 2009. Changes of main secondary metabolites in leaves of Ginkgo biloba in response to ozone fumigation. Journal of Environment Sciences 21:199-203

IPCC. 2013. Climate change, 2013: The physical science basis. Cambridge, UK: Cambridge University Press.

Julkunen-Tiitto R. 1985. Phenolic constituents in the leaves of northern willows: Methods for the analysis of certain phenolics. Agricultural and Food Chemistry 33: 213-217

Kainulainen P, Holopainen T, Holopainen JK. 2003. Decomposition of secondary compounds from needle litter of Scots pine grown under elevated $\mathrm{CO}_{2}$ and $\mathrm{O}_{3}$. Global Change Biology 9: 295-304

Lavola A, Julkunen-Tiitto R, Paakkonen E 1994. Does ozone stress change the primary or secondary metabolites of birch (Betula pendula Roth.) ? New Phytologist 126: 637-642

Li XM, Zhang LH, Li YY, Ma LJ, Chen Q, Wang LL, He XY. 2011. Effects of elevated carbon dioxide and/or ozone on endogenous plant hormones in the leaves of Ginkgo biloba. Acta Physiologiae Plantarum 33: 129-136

Lindroth R, Kopper BJ, Parsons WFJ, Bockheim JG, Karnosky DFK, Hendrey GR, Pregitzer KS, Isebrands JG, Sober J. 2001. Consequences of elevated carbon dioxide and ozone for foliar chemical composition and 
353

354

355

356

357

358

359

360

361

362

363

364

365

366

367

368

369

370

371

372

373

374

375

376

377

378

379

380

381

382

383

384

385

386

387

388

389

dynamics in trembling aspen (Populus tremuloides) and paper birch (Betula papyrifera). Environmental Pollution 115: 395-404

Liu FR, Chen HY, Liu Y, Wei ZM. 2004. Changes in solute content of different tomato genotypes under salt stress. Acta Photophysiologica Sinica 30: 99-104

Liu L, King JS, Giardina CP, Booker FL. 2009. The influence of chemistry, production and community composition on leaf litter decomposition under elevated atmospheric $\mathrm{CO}_{2}$ and tropospheric $\mathrm{O}_{3}$ in a northern hardwood ecosystem. Ecosystems 12: 401-416

Liyama K, Wallis AFA. 1988. An improved acetyl bromide procedure for determining lignin in woods and wood pulps. Wood Science and Technology 22: 271-280

Lu G, Huang Y, Chen H, Xu L. 2012. Effects of ozone on membrane lipid peroxidation and protective enzyme activities of Thevetia peruviana and Mangifera leaves. Ecology \& Environment Sciences 21: 1235-1240

Lu T, He XY, Chen W, Yan K, Zhao TH. 2009. Effects of elevated $\mathrm{O}_{3}$ and/or elevated $\mathrm{CO}_{2}$ on lipid peroxidation and antioxidant systems in Ginkgo biloba leaves. Bulletin of Environment Contamination Toxicology 83: 92-96

Luo Z, Zhang L. 2010. Effects of $\mathrm{O}_{3}$ on lignifications and related enzyme activity in bamboo shoots. Transaction Chinese Society Agricultural Machinery 41: 115-117

Manes F, Incerti G, Salvatori E, Vitale M, Ricotta C, Costanza R. 2012. Urban ecosystem services: tree diversity and stability of tropospheric ozone removal. Ecological applications 22: 349-360

Nikolova PS, Andersen CP, Blaschke H, Matyssek R, Haberle KH. 2010. Belowground effects of enhanced tropospheric ozone and drought in a beech/spruce forest (Fagus sylvatica L./Picea abies [L.] Karst). Environmental Pollution 158: 1071-1078

Nikula S, Vapaavuori E, Manninen S. 2010. Urbanization-related changes in European aspen (Populus tremula L.): Leaf traits and litter decomposition. Environmental Pollution 158: 2132-2142

Olson JS. 1963. Energy storage and the balance of producers and decomposers in ecological systems. Ecology 44: 322-31

Pancotto VA, Sala OE, Cabello M, Lopez NI, Robson TM, Ballare CL, Caldwell MM, Scopel AL. 2003. Solar UV-B decreases decomposition in herbaceous plant litter in Tierra del Fuego, Argentina: potential role of an altered decomposer community. Global Change Biology 9: 1465-1474

Paoletti E. 2006. Impact of ozone on Mediterranean forests: a review. Environmental Pollution 144: 463-474

Parsons WF, Bockheim JG, Lindroth RL. 2008. Independent, interactive, and species-specific responses of leaf litter decomposition to elevated $\mathrm{CO}_{2}$ and $\mathrm{O}_{3}$ in a northern hardwood forest. Ecosystems 11: 505-519

Parsons WFJ, Lindroth RL, Bockheim JG. 2004. Decomposition of Betula papyrifera leaf litter under the independent and interactive effects of elevated $\mathrm{CO}_{2}$ and $\mathrm{O}_{3}$. Global Change Biology 10:1666-1677

Peace EA, Lea PJ, Darrall NM. 1995. The effect of open-air fumigation with $\mathrm{SO}_{2}$ and $\mathrm{O}_{3}$ on carbohydrate metabolism in Scots pine (Pinus sylvestris) and Norway spruce (Picea abies). Plant, Cell \& Environment 18: 277-283

Peltonen PA, Vapaavuori E, Julkunen-Titto R. 2005. Accumulation of phenolic compounds in birch leaves is 
changed by elevated carbon dioxide and ozone. Global Change Biology 11: 1305-1324

Peng SL, Liu Q. 2002. The dynamics of forest litter and its responses to global warming. Acta Ecologica Sinica 22: $1534-1544$

Porter LJ, Hrstich LN, Chan BG. 1986. The conversion of procyanidins and prodelphinidins to cyanidin and delphinidin. Phytochemistry 25: 223-230

Scherzer AJ, Rebbeck J, Boerner REJ. 1998. Foliar nitrogen dynamics and decomposition of yellow-poplar and eastern white pine during four seasons of exposure to elevated ozone and carbon dioxide. Forest Ecology and Management 109: 355-366

Shang B, Feng Z, Li P, Calatayud V. 2018. Elevated ozone affects C, N and P ecological stoichiometry and nutrient resorption of two poplar clones. Environmental Pollution 234: 136-144

Sicard P, Augustaitis A, Belyazid S, Calfapietra C, Marco AD, Fenn M, Bytnerowicz A, Grulke N, He S, Matyssek R, Serengil Y, Wieser G, Paoletti E. 2016. Global topics and novel approaches in the study of air pollution, climate change and forest ecosystems. Environmental Pollution 213:977-987

Sitch S, Cox PM, Collins WJ, Huntingford C. 2007. Indirect radiative forcing of climate change through ozone effects on the land-carbon sink. Nature 448: 791-794

Su L, Xu S, Fu W, He X, Chen W, Zhao Y, Ping Q. 2016. Effects of elevated $\mathrm{O}_{3}$ on the leaf litter decomposition and nutrient release of Quercus mongolica in city. Chinese Journal of Applied Ecology 27: 373-379

Tiwari P, Sangwan RS, Sangwan NS. 2016. Plant secondary metabolism linked glycosyltransferases: An update on expanding knowledge and scopes. Biotechnology Advances 34: 714-739

Tjoelker MG, Luxmoore RJ. 1991. Soil nitrogen and chronic ozone stress influence physiology, growth, and nutrient status of Pinus taeda L. and Liriodendron tulipifera L. seedlings. New Phytologist 119: 69-81

Wang B, Shugart HH, Shuman JK, Lerdau MT. 2016. Forests and ozone: productivity, carbon storage, and feedbacks. Scientific reports 6: 22133

Wang Y, Wang X, Zhou X, Yang L, Zhu J, Kobayashi K, Wang Y. 2011. Impacts of tropospheric ozone concentration enrichment on lodging resistance of rice Wuyuanjing 21. Jiangsu Journal of Agricultural Science 27: 1167-1173

Xu S, He X, Chen W, Huang Y, Zhao Y, Li B. 2015. Differential sensitivity of four urban tree species to elevated $\mathrm{O}_{3}$. Urban Forest \& Urban Greening 14: 1166-1173

Xu S, Xu W, Chen W, He X, Huang Y, Wen H. 2014. Leaf phonological characters of main tree species in urban forest of Shenyang. PLOSone 9: e99277

Xu W, Chen W, He X, Xu S, Zhang Y, Wen H. 2012. Litterfall amount and dynamics in urban forest of Shenyang. Chinese Journal of Applied Ecology 23: 2931-2939

Xu W, He X, Chen W, Hu J, Wen H. 2006. Responses of Shenyang urban tree phenology to climate warming. Chinese Journal of Applied Ecology 17: 1777-1781

Xu W, He X, Chen W, Liu C, Sun Y. 2005. Microclimate characters of urban forest in Shenyang City. Chinese Journal of Applied Ecology 16: 1650-1654

Yamaji K, Julkunen-Tiitto R, Rousi M, Freiwald V, Oksanen E, 2003. Ozone exposure over two growing 
seasons alters root-to-shoot ratio and chemical composition of birch (Betula pendula Roth). Global Change Biology 9: 1363-1377

Zhang G, He X, Tang L, Yan K, Chen W, Xu S, Li X. 2009. Effects of elevated ozone on phenolic substances content and total antioxidative capacity of Quercus mongolica leaves. Chinese Journal of Applied Ecology 20: $725-728$

Zhang X, Liu Z, Yu Q, Luc NT, Bing Y, Zhu B, Wang W. 2015. Effect of petroleum on decomposition of shrubgrass litters in soil in Northern Shaanxi of China. Journal of Environmental Sciences 33: 245-253 Ecology 30:1637-1641 


\section{Tables and Figure legends}

472 Table 1 The physical and chemical properties of topsoil $(0-10 \mathrm{~cm})$ in OTCs before leaf litter decomposition of $G$. biloba

Table 2 Microclimatic conditions in OTCs during gas fumigation in 2013

Table 3 Parameters of decomposition rate of $G$. biloba litter leaves exposed to elevated $\mathrm{O}_{3}$ concentration

Table 4 Summary of the GLM testing (type III Sum of Squares, in bold values significant at $\mathrm{p}<0.05$ ) for effects of $\mathrm{O}_{3}$ treatments and decomposition time ( $T$ ) on mass and nutrients remaining of leaf litter in G. biloba

Table 5 Spearman correlations coefficients of remaining mass to initial with nutrient contents dynamics during decomposition of

Figure 1 Seasonal variations in $\mathrm{O}_{3}$ concentrations in OTCs with ambient air (AA) and elevated $\mathrm{O}_{3}$ (EO) during leaf litter decomposition. Each point represents a mean daily value (09: 17:00).

Figure 2 Leaf chemistry changes in G. biloba as affected by $\mathrm{O}_{3}$ concentration. Data refer to mean and standard deviation of the carbon (C) content, nutrients (N, P, K), C-to-N ratio, total phenolics (TP), condensed tannins (CT) and soluble sugars (SS) in leaf samples $(\mathrm{N}=3)$ of the target specie after 3 months of daily exposure to elevated $\mathrm{O}_{3}$ concentration $(120$ ppb), expressed as percentage of corresponding data observed under ambient air (AA, $40 \mathrm{ppb}$ ). Significant changes are shown $(*, P<0.05 ; * *, P<$ $0.01)$.

486 Figure 3 The remaining of mass, contents of C, N and P, lignin, total phenolics, condensed tannins and soluble sugars (A-H) in leaf litter of $G$. biloba under elevated $\mathrm{O}_{3}$ concentration (EO, $120 \mathrm{ppb}$ ) and ambient air (AA, $\left.40 \mathrm{ppb}\right)$ for 150 days. Data refer to $(*, P<0.05 ; * *, P<0.01)$. 


\section{Table $\mathbf{1}$ (on next page)}

The physical and chemical properties of topsoil $(0-10 \mathrm{~cm})$ in OTCs before leaf litter decomposition of $G$. biloba 
Table 1 The physical and chemical properties of topsoil $(0-10 \mathrm{~cm})$ in OTCs before leaf litter decomposition of

G. biloba

\begin{tabular}{|c|c|c|c|c|c|c|c|c|c|c|}
\hline Treatments & $\mathrm{pH}$ & $\begin{array}{c}\text { SWC } \\
(\%)\end{array}$ & $\begin{array}{c}\mathrm{ST} \\
\left({ }^{\circ} \mathrm{C}\right)\end{array}$ & $\begin{array}{c}\mathrm{SOC} \\
(\mathrm{mg} / \mathrm{g})\end{array}$ & $\begin{array}{c}\mathrm{C} \\
(\mathrm{mg} / \mathrm{g})\end{array}$ & $\begin{array}{c}\mathrm{N} \\
(\mathrm{mg} / \mathrm{g})\end{array}$ & $\begin{array}{c}\mathrm{P} \\
(\mathrm{mg} / \mathrm{g})\end{array}$ & $\begin{array}{c}\mathrm{K} \\
(\mathrm{mg} / \mathrm{g})\end{array}$ & $\mathrm{C} / \mathrm{N}$ & $\mathrm{C} / \mathrm{P}$ \\
\hline \multirow[t]{3}{*}{$\mathrm{AA}$} & 6.75 & 28.25 & 25.50 & 9.12 & 33.23 & 2.54 & 4.44 & 5.70 & 13.10 & 7.48 \\
\hline & $(0.06)$ & (1.08) & $(0.82)$ & $(0.30)$ & $(0.79)$ & $(0.03)$ & $(0.09)$ & $(0.08)$ & $(0.40$ & $(0.27)$ \\
\hline & & & & & & & & & & \\
\hline \multirow[t]{2}{*}{ EO } & 6.67 & 28.34 & 25.30 & 9.20 & 34.12 & 2.58 & 4.35 & 5.44 & 13.22 & 7.85 \\
\hline & $(0.03)$ & $(0.97)$ & (1.15) & $(0.04)$ & (0.19) & $(0.01)$ & $(0.06)$ & $(0.43)$ & $(0.11)$ & $(0.06)$ \\
\hline
\end{tabular}

Data are shown mean and standard deviation $(\mathrm{SD})$ in the parenthesis $(\mathrm{n}=3)$. AA-ambient air (control), EO-elevated

$\mathrm{O}_{3}$, SWC-soil water content, ST-soil temperature. SOC-soil organic matter content. 
Table 2 (on next page)

Microclimatic conditions in OTCs during gas fumigation in 2013 
Table 2 Microclimatic conditions in OTCs during gas fumigation in 2013

\begin{tabular}{cccccccc}
\hline Treatments & {$\left[\mathrm{O}_{3}\right]_{\text {mean }}$} & {$\left[\mathrm{O}_{3}\right]_{\max }$} & $\mathrm{AOT40}(150)$ & & & {$\left[\mathrm{CO}_{2}\right]$} & DPPFD \\
& & & & $\mathrm{RH}_{\text {mean }}$ & $\mathrm{T}_{\text {mean }}$ & & \\
\hline AA & 38.2 & 76.5 & 1167.5 & 68.3 & 23.8 & 372.4 & 46.9 \\
\hline EO & 119.5 & 126.0 & $77,246.1$ & 66.9 & 24.1 & 368.9 & 46.5 \\
\hline
\end{tabular}

$\left[\mathrm{O}_{3}\right]_{\text {mean, }}$, average daily $(08:-17: 00)$ concentrations of $\mathrm{O}_{3}(\mathrm{ppb})$; $\left[\mathrm{O}_{3}\right] \mathrm{max}$, average maximum daily concentrations of $\mathrm{O}_{3}(\mathrm{ppb})$; AOT40, cumulative the sum of the differences between the hourly mean ozone concentration in ppb and $40 \mathrm{ppb}$ for each hour of gas exposure; AOT40 ${ }^{(150)}$, indicates the accumulated values of AOT40 during the 150-day decomposition experiment (ppb·h); $\mathrm{RH}_{\text {mean }}$, average daily air relative humidity (\%); $\mathrm{T}_{\text {mean }}$, average daily air temperature $\left({ }^{\circ} \mathrm{C}\right)$. AA-ambient air, EO-elevated $\mathrm{O}_{3} .\left[\mathrm{CO}_{2}\right]_{\text {mean, }}$ average air $\mathrm{CO}_{2}$ concentration in OTC $(\mu$ mol $\left.\mathrm{mol}^{-1}\right)$; DPPFD, average daily photosynthetic photo flux density at the canopy level $\left(\mathrm{mol} \mathrm{m}^{-2} \mathrm{day}^{-1}\right)$. 


\section{Table 3(on next page)}

Parameters of decomposition rate of G. biloba litter leaves exposed to elevated $\mathrm{O}_{3}$ concentration 
Table 3 Parameters of decomposition rate of $G$. biloba litter leaves exposed to elevated $\mathrm{O}_{3}$ concentration

\begin{tabular}{ccccc}
\hline Treatments & Olson exponential decay & $R^{2}$ & Decay constants $(\mathrm{K})$ & $\mathrm{t}_{0.5} / \mathrm{a}$ \\
\hline AA & $\mathrm{y}=0.8512 \mathrm{e}^{-1.17 \mathrm{x}}$ & 0.73 & 1.17 & 0.46 \\
\hline EO & $\mathrm{y}=0.8749 \mathrm{e}^{-1.39 \mathrm{x}}$ & 0.84 & 1.39 & 0.41 \\
\hline
\end{tabular}

AA-ambient air, EO-elevated $\mathrm{O}_{3}$. No significant difference in each parameter was found between AA and EO. 
Table 4 (on next page)

Summary of the GLM testing (type III Sum of Squares, in bold values significant at $p<0.05$ ) for effects of $\mathrm{O}_{3}$ treatments and decomposition time $(T)$ on mass and nutrients remaining of leaf litter in $G$. biloba 
Table 4 Summary of the GLM testing (type III Sum of Squares, in bold values significant at $\mathrm{p}<0.05$ ) for effects of $\mathrm{O}_{3}$ treatments and decomposition time $(T)$ on mass and nutrients remaining of leaf litter in G. biloba

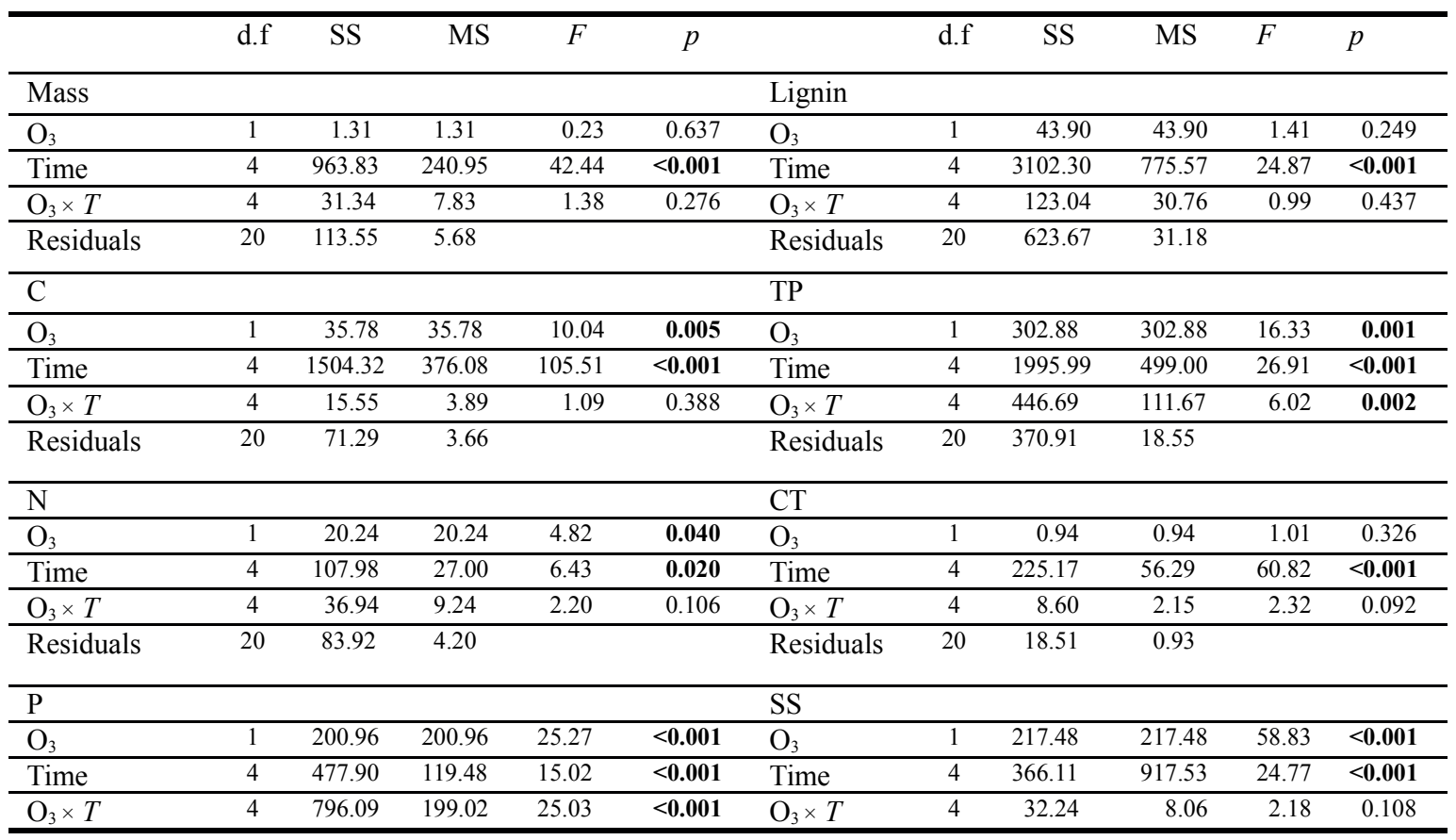

TP-total phenols, CT-condensed tannin, SS-soluble sugar 
Table 5(on next page)

Spearman correlations coefficients of remaining mass to initial with nutrient contents dynamics during decomposition of $G$. biloba leaf litter 
Table 5 Spearman correlations coefficients of remaining mass to initial with nutrient contents dynamics during decomposition of G. biloba leaf litter

\begin{tabular}{ccclllll}
\hline & Treatments & $\begin{array}{c}\text { Remaining } \\
\text { mass }\end{array}$ & $\mathrm{C}$ & $\mathrm{N}$ & $\mathrm{C} / \mathrm{N}$ & $\mathrm{P}$ & Lignin \\
\hline $\begin{array}{c}\text { Remaining } \\
\text { mass }\end{array}$ & -0.07 & & & & & & \\
\hline $\mathrm{C}$ & -0.07 & $0.96^{* *}$ & & & & & \\
\hline $\mathrm{N}$ & 0.12 & $0.33^{*}$ & 0.28 & & & & \\
\hline $\mathrm{C} / \mathrm{N}$ & -0.17 & $0.91^{* *}$ & $0.96^{* *}$ & 0.17 & & & \\
\hline $\mathrm{P}$ & 0.28 & $0.79^{* *}$ & $0.79^{* *}$ & $0.48^{* *}$ & $0.66^{* *}$ & & \\
\hline Lignin & $-0.36^{*}$ & $0.66^{* *}$ & $0.66^{* *}$ & 0.28 & $0.75^{* *}$ & $0.36^{*}$ & \\
\hline Lignin $/ \mathrm{N}$ & -0.32 & $0.63^{* *}$ & $0.67^{* *}$ & 0.19 & $0.78^{* *}$ & $0.34^{*}$ & $0.95^{* *}$ \\
\hline$* P<0.05 * * P<0.01$. & & & & & & & \\
\hline
\end{tabular}




\section{Figure 1 (on next page)}

Seasonal variations in $\mathrm{O}_{3}$ concentrations in OTCs with ambient air (AA) and elevated $\mathrm{O}_{3}$ (EO) during leaf litter decomposition 


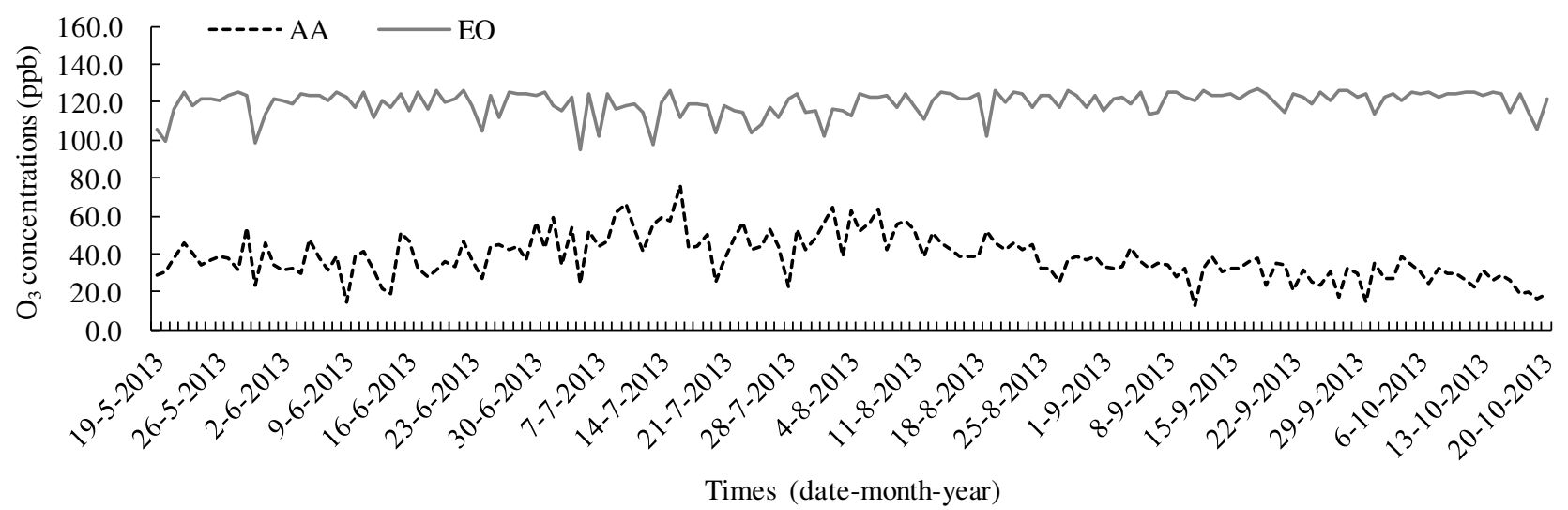


Figure 2 (on next page)

Leaf chemistry changes in $\mathrm{G}$. biloba as affected by $\mathrm{O}_{3}$ concentration 


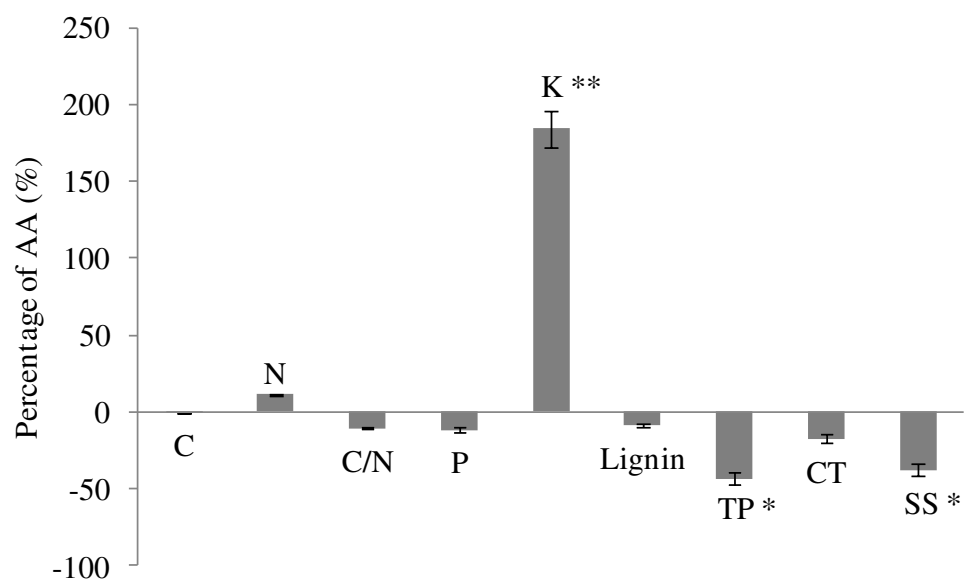


Figure 3 (on next page)

The remaining of mass, contents of $\mathrm{C}, \mathrm{N}$ and $\mathrm{P}$, lignin, total phenolics, condensed tannins and soluble sugars (A-H) in leaf litter of $\mathrm{G}$. biloba under elevated $\mathrm{O}_{3}$ concentration (EO, $120 \mathrm{ppb}$ ) and ambient air (AA, $40 \mathrm{ppb}$ ) for 150 days 

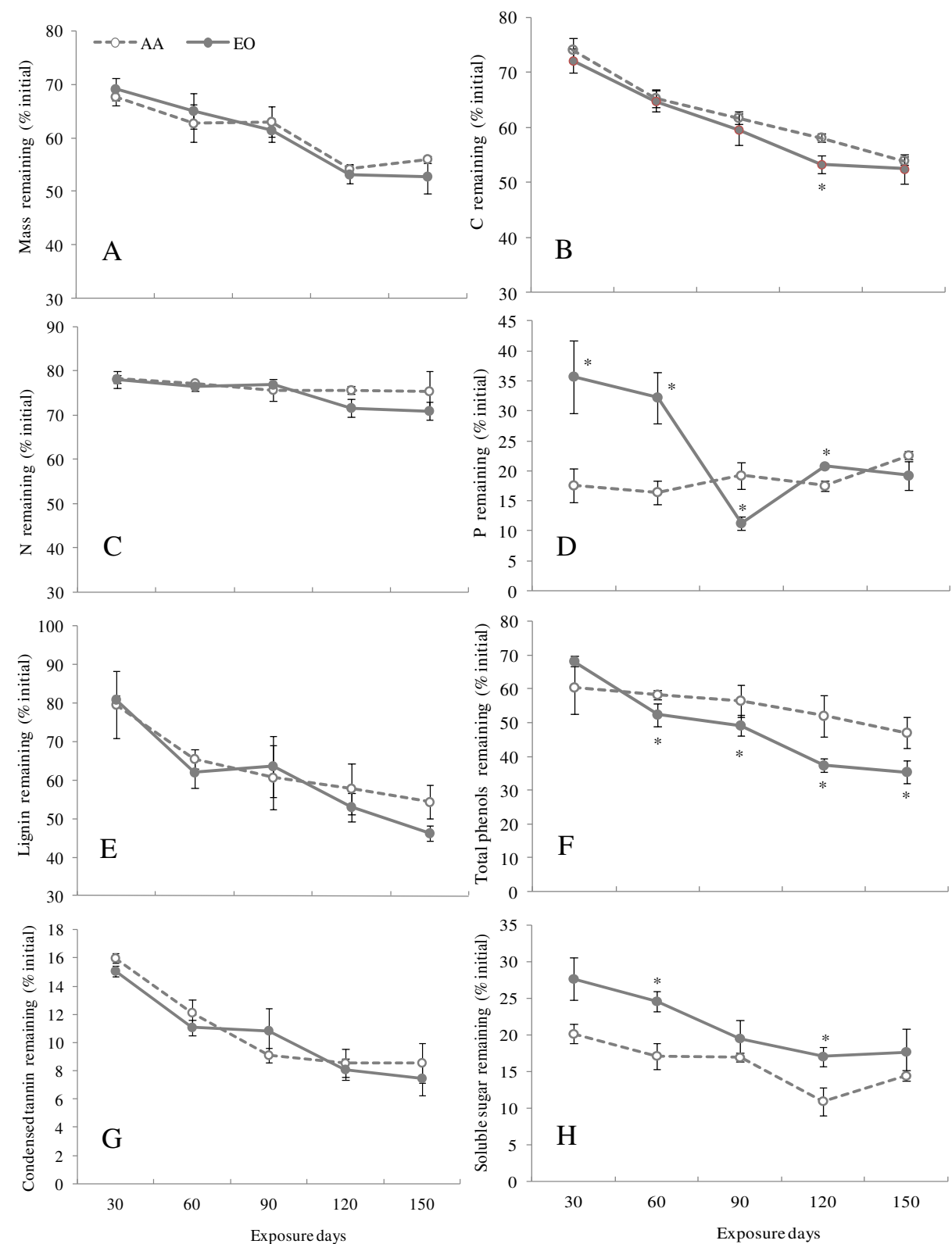